\title{
Branched-chain Amino Acid Biosynthesis in the Blue-green Alga Anabaena variabilis
}

\author{
By W. HOOD* AND N. G. CARR \\ Department of Biochemistry, University of Liverpool, \\ P.O. Box I 47, Liverpool, $L 693 B X$
}

(Received 15 May 1972; revised 3 July 1972)

\begin{abstract}
SUMMARY
Four enzymes (threonine deaminase, $\alpha$-acetohydroxyacid synthetase, isopropylmalate synthetase and transaminase B) involved in leucine, isoleucine and valine synthesis have been detected in extracts of the blue-green alga Anabaena variabilis and the control of three of the enzymes examined. A new procedure for the determination of transaminase $B$ is described. Threonine deaminase and $\alpha$-acetohydroxyacid synthetase are subject to feedback control by their end-products. No evidence for the repression of enzyme synthesis in the pathway has been found, although the assimilation and incorporation of exogenous valine and leucine was demonstrated.
\end{abstract}

\section{INTRODUCTION}

Previous results have indicated that several major intermediary metabolic sequences in the blue-green algae, Anabaena variabilis and Anacystis nidulans, are not regulated by the process of repression and derepression of enzyme biosynthesis (Pearce \& Carr, 1967, 1969; Pearce, Leach \& Carr, I969). Blue-green algae are known to excrete large quantities of amino acids as peptides during growth. We have previously suggested that this may be a result of inability to control the synthesis of amino acids. No evidence of repression of the enzymes involved in the synthesis of arginine from glutamate by $A$. variabilis was observed when the arginine was added to the growth medium, although it was incorporated into protein (Hood \& Carr, 197I). Similarly, the inclusion in the growth medium of aromatic amino acids did not reduce the level of 3-deoxy-D-arabinoheptulosonic acid-7-phosphate synthetase in $A$. nidulans (Weber \& Böck, I968).

The pathway of biosynthesis of valine, isoleucine and leucine has been elucidated in several micro-organisms (see Meister, 1957) and is unusual in that four enzymes (acetohydroxyacid synthetase, acetohydroxyacid isomeroreductase, dihydroxyacid dehydrase and transaminase B) are common to the synthesis of all three amino acids. The control of the synthesis of branched-chain amino acids, by both repression of enzyme synthesis and by feedback inhibition, has been well documented in several bacteria (see Umbarger, 1969). This communication describes some regulatory aspects of valine, leucine and isoleucine biosynthesis in obligately autotrophic blue-green algae; a preliminary account of some of the data has been presented (Hood \& Carr, I968).

* Present address: Department of Pathology, Mytton Oak Road, Shrewsbury, SY 38 XH.

Vol. 72, No. 2, was issued 6 December 1972 
Organisms and culture conditions. The Anabaena variabilis employed was the non-nitrogen fixing strain of Professor J. Myers, Department of Zoology, University of Texas, Austin. Anacystis nidulans was from the Culture Collection of Algae (no. 625) at Indiana University and Escherichia coli from the N.C.I.B. (no. 8II4), Torry Research Station, Aberdeen. Blue-green algae were maintained and cultured as previously described (Pearce \& Carr, 1967). The autotrophic growth medium C (Kratz \& Myers, 1955) was supplemented with $0.5 \% \mathrm{NaHCO}$, and, where indicated, with L-valine, L-leucine, or L-isoleucine. Flasks (5 l) were gassed with air: $\mathrm{CO}_{2}(95: 5)$ and were placed $23 \mathrm{~cm}$ from $60 \mathrm{~W}$ warm-white fluorescent lamps and maintained at $34^{\circ} \mathrm{C}$. Escherichia coli was grown in the mineral salt medium of Davis \& Mingioli (I950) plus glucose (2 g/l) and, where indicated, with L-valine, L-leucine or L-isoleucine.

Preparation of cell-free extracts. Anacystis nidulans and Escherichia coli were harvested at room temperature at $3000 \mathrm{~g}$ for I $5 \mathrm{~min}$ whilst Anabaena variabilis required only $1500 \mathrm{~g}$ for $5 \mathrm{~min}$. Organisms were washed twice with $5 \mathrm{~mm}$-potassium phosphate, $\mathrm{pH} 7 \cdot 0$, suspended (20 to $25 \mathrm{mg} / \mathrm{ml}$ ) in a small volume of the same buffer and disrupted at $2{ }^{\circ} \mathrm{C}$ by three $30 \mathrm{~s}$ bursts (separated by $\mathrm{I} .5 \mathrm{~min}$ intervals to prevent overheating) in an MSE $60 \mathrm{~W} 20 \mathrm{kc} / \mathrm{s}$ sonic disintegrator. Unbroken organisms and cell debris were removed by centrifugation at $10000 \mathrm{~g}$ for $15 \mathrm{~min}$ at $0^{\circ} \mathrm{C}$.

Determination of growth rate and incorporation of $U-{ }^{14} \mathrm{C}$ amino acids into blue-green algae. Cultures of blue-green algae $(100 \mathrm{ml})$ were grown in $250 \mathrm{ml}$ conical flasks to which side arms capable of fitting into an EEL colorimeter were annealed, in a Gallenkamp Illuminated Orbital Incubator at $34^{\circ} \mathrm{C}$ which was continually flushed with air: $\mathrm{CO}_{2}(95 \cdot 5)$. Light was supplied by four $60 \mathrm{~W}$ warm-white fluorescent lamps $30 \mathrm{~cm}$ above the cultures. Growth was measured turbidimetrically and dry weight was determined by reference to a standard curve. When determining the rate of incorporation of ${ }^{14} \mathrm{C}$ amino acids, samples were removed and the organisms collected by membrane filtration (Millipore Filter, HAWP, $0.45 \mu$ ). The filters were washed Io times with $5 \mathrm{mM}$-potassium phosphate $(\mathrm{pH} 7 \cdot 0)$ to remove extraneous ${ }^{14} \mathrm{C}$ acid, and then dried. Isotopic incorporation was measured, in duplicate, in a Nuclear Chicago Gas Flow Planchet Counter at an efficiency of $24 \%$. Sufficient counts were recorded to ensure an accuracy of at least $\mathrm{I} \%$. Fractionation of blue-green algae after growth on ${ }^{14} \mathrm{C}$ amino acids was carried out by the procedure of Roberts et al. (1955).

\section{Enzyme assays}

$\beta$-Aspartokinase (ATP: L-aspartate 4-phosphotransferase; EC. 2.7.2.4). Reaction mixtures were prepared according to Black \& Wright (1955) and the formation of the hydroxamic acid resulting from the action of hydroxylamine with acyl phosphate was determined by the method of Lipmann \& Tuttle (1945).

$\alpha$-Acetohydroxyacid synthetase (acetolactate synthetase). The procedure of Radhakrishnan $\&$ Snell (I960) was used, the acetolactate synthesized was converted to acetoin by heating and this was determined by the colorimetric procedure of Westerfeld (1945).

Threonine deaminase (threonine dehydrase, EC. 4.2.1.I). This enzyme was estimated by measuring the amount of $\alpha$-ketobutyrate formed from threonine by the method of Friedemann \& Haugen (1943). Reaction mixtures were prepared according to Yanofsky \& Reissig (I953) and incubated for $\mathrm{I} h$.

$\alpha$-Isopropylmalate synthetase. The formation of free sulphydryl groups, measured by the procedure of Grunert \& Phillips (I95I), resulting from the condensation of acetyl CoA 
and $\alpha$-ketoisovalerate, formed the basis of this assay (Burns, Calvo, Margolin \& Umbarger, I966).

Transaminase B. A procedure was developed for the measurement of transaminase B activity based on the selective solubility of the 2,4-dinitrophenylhydrazones of the product and substrate keto acids. Reaction mixtures contained ( $\mu$ moles): potassium phosphate buffer $(\mathrm{pH} 7 \cdot 0), 200 ; \alpha$-ketoisovalerate, 3.3; L-glutamate sodium salt, 20; pyridoxal phosphate, 0.04 ; and o to $16 \mathrm{mg}$ of algal protein in a total volume of $2.0 \mathrm{ml}$. Alanine or aspartate may replace glutamate as the amino group donor. After incubation $\left(30 \mathrm{~min}\right.$ ) at $34^{\circ} \mathrm{C}$, the reaction was stopped by addition of $\mathrm{I} \cdot 0 \mathrm{ml}$ of $10 \%$ trichloroacetic acid and the precipitated protein was removed by centrifugation. The deproteinized supernatants were added to $0.4 \mathrm{ml}$ of a $\mathrm{I} \%$ solution of 2,4 -dinitrophenylhydrazine in $2 \mathrm{~N}-\mathrm{HCl}$ and incubated for $30 \mathrm{~min}$. The 2,4-dinitrophenylhydrazones of both $\alpha$-ketoisovalerate and $\alpha$-oxoglutarate were dissolved in $8 \mathrm{ml}$ of ethyl acetate. After vigorous shaking the lower aqueous layer was removed by a pipette and $10 \%$ sodium carbonate $(6 \mathrm{ml})$ added to the ethyl acetate. Only the 2,4-dinitrophenylhydrazone of the product keto acid, $\alpha$-oxoglutarate (or pyruvate or oxaloacetate when alanine or aspartate were used as the amino group donors) was soluble in the aqueous layer, the 2,4-dinitrophenylhydrazone of the substrate keto acid, $\alpha$-ketoisovalerate remained in the ethyl acetate. A major portion $(5 \mathrm{ml})$ of the lower aqueous layer was removed and added to an equal volume of $\mathrm{I} \cdot 5 \mathrm{~N}-\mathrm{NaOH}$. The extinction was measured at the absorption maxima for the appropriate 2,4-dinitrophenylhydrazone (4IO $\mathrm{nm}$ for $\alpha$-oxoglutarate, $445 \mathrm{~nm}$ for pyruvate, $450 \mathrm{~nm}$ for $\alpha$-oxaloacetate) and compared with a standard curve of the authentic keto acid derivative. The formation of valine from $\alpha$-ketoisovalerate was demonstrated by incubating the assay mixture with extract from Anabaena variabilis and terminating the reaction by the addition of acetic acid $(0.2 \mathrm{ml})$ and $95 \%$ ethanol $(0.8 \mathrm{ml})$. The deproteinized supernatant was co-chromatographed on paper with authentic valine in $n$-propanol:water $(4: \mathrm{I}, \mathrm{v} / \mathrm{v})$ and ethanol:ammonia:water (I8:I:I, by vol.). The position of the valine was located by spraying with $\mathrm{I} \%$ ninhydrin in acetone. The 2,4-dinitrophenylhydrazone derivatives of the keto acids resulting from $A$. variabilis transaminase $\mathrm{B}$ activity were identified by paper chromatography using $n$-butanol:ethanol: water : ammonia (140:20:40:1, by vol.); methanol:benzene: $n$-butanol:water $(2: \mathrm{I}: \mathrm{I}: \mathrm{I}$, by vol.); $n$-butanol: $\mathrm{N}$-sodium carbonate $(\mathrm{I}: 2, \mathrm{v} / \mathrm{v})$.

Hydrolysis of intact organisms. Anabaena variabilis, after growth in the presence of labelled compounds, were harvested and washed twice in the presence of the same unlabelled substrate and then hydrolysed in $6 \mathrm{~N}-\mathrm{HCl}$ in a sealed pyrex tube at $108^{\circ} \mathrm{C}$ for $16 \mathrm{~h}$. The $\mathrm{HCl}$ was removed from the hydrolysates by drying for $24 \mathrm{~h}$ under vacuum. The residue was taken up in I $\mathrm{ml}$ of warm water and filtered. The filtrates were extracted twice with equal volumes of ethyl ether and the other extracts were discarded. The aqueous layer was dried under vacuum and the residue taken up in less than $\mathrm{I} \mathrm{ml}$ of isopropanol and water $(20: 80$, $\mathrm{v} / \mathrm{v})$. The components were separated by two dimensional thin-layer chromatography on cellulose plates by using $n$-butanol:acetic acid:water ( $12: 3: 5$, by vol.) followed by ethanol: ammonia:water (I8:I:I, by vol). Autoradiograms were obtained using Kodirex X-ray film.

Chemicals. All chemicals were of analytical grade or of the purest commercial grade available and were, with the exceptions listed below, obtained from British Drug House Ltd, Poole, Dorset, England. ATP, coenzyme A and flavin adenine dinucleotide were obtained from C. F. Boehringer and Soehne GmbH., Mannheim, Germany; $\alpha$-ketoisovaleric acid, $\alpha$-ketoisocaproic acid, pyridoxal phosphate and thiamine pyrophosphate were obtained from Sigma Chemical Co. Ltd, London, W. $6 ; \alpha$-ketoisobutyric acid was obtained 

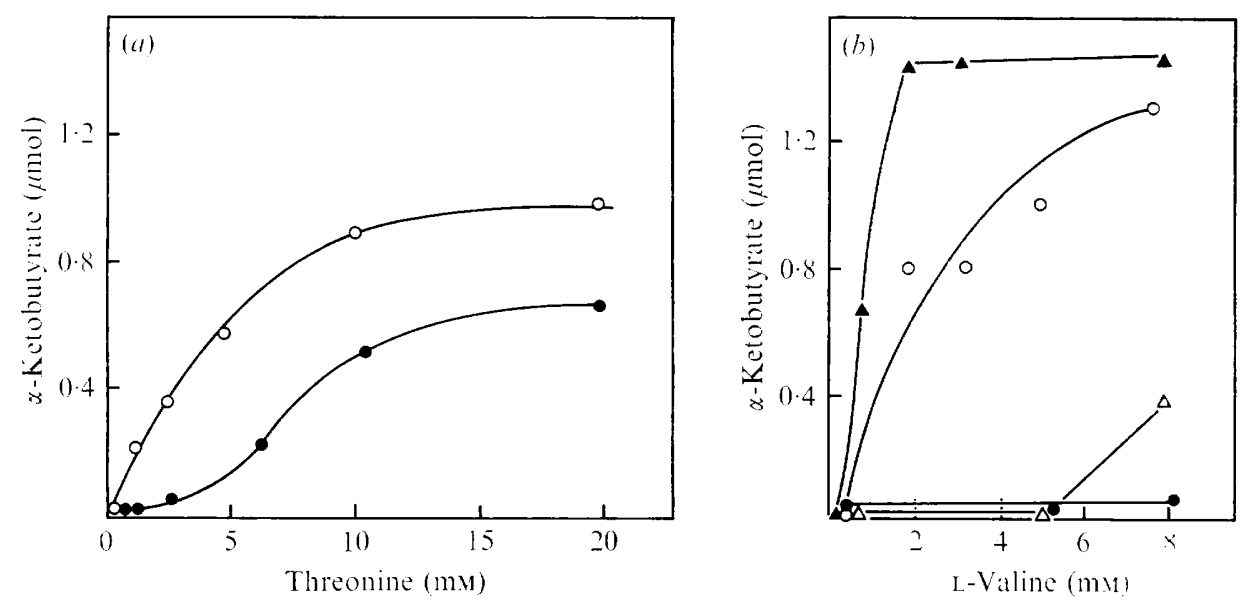

Fig. I (a). Inhibition of threonine deaminase of Anabaena variabilis by isoleucine, and restoration of activity by increased threonine. Each reaction mixture contained $2 \mathrm{mg}$ protein; $\bigcirc-0$, standard assay mixture except for threonine concentration, - , as above plus L-isoleucine $\left(6 \cdot 6 \times 10^{-2} \mathrm{~mm}\right)$.

Fig. I (b). Antagonism by valine of the isoleucine inhibition of threonine deaminase from Anabaena variabilis. $\mathbf{\Delta}-\mathbf{\Delta}$, Standard reaction mixture plus L-isoleucine $\left(\mathrm{IO}^{-4} \mathrm{M}\right) ; \mathrm{O}-\mathrm{O}$, standard plus $\mathrm{L}^{-}$ isoleucine $\left(2 \times 10^{-4} \mathrm{M}\right) ; \triangle-\triangle$, standard plus L-isoleucine $\left(3 \times \mathrm{IO}^{-4} \mathrm{M}\right) ; \mathbf{O}-\mathbf{C}$, standard plus L-isoleucine $\left(5 \times \mathrm{IO}^{-4} \mathrm{M}\right)$.

Table I. Effect of inclusion of branched-chain amino acids in the growth medium of Anabaena variabilis on the activities of three enzymes involved in their biosynthesis

\begin{tabular}{|c|c|c|}
\hline Enzyme & $\begin{array}{l}\text { Additions to } \\
\text { growth medium }\end{array}$ & $\begin{array}{c}\text { Activity } \\
(\mathrm{nmol} / \mathrm{h} / \mathrm{mg})\end{array}$ \\
\hline Threonine deaminase & $\left.\begin{array}{l}\text { None } \\
\text { + L-Isoleucine }(\mathrm{I} \cdot 5 \mathrm{~mm}) \\
\text { L-Isoleucine } \\
\text { L-Valine } \\
\text { L-Leucine }\end{array}\right\}$ & $\begin{array}{l}0.5 \mathrm{I} \\
0.48 \\
0.57\end{array}$ \\
\hline $\begin{array}{l}\alpha \text {-Acetohydroxyacid } \\
\text { synthetase }\end{array}$ & 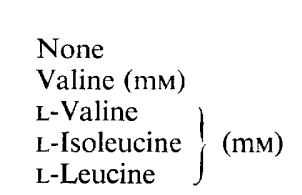 & $\begin{array}{l}30 \\
27 \\
24\end{array}$ \\
\hline Transaminase B & $\left.\begin{array}{l}\text { L-Valine } \\
\text { L-Leucine } \\
\text { L-Isoleucine } \\
\text { None }\end{array}\right\}(\mathrm{mm})$ & $\begin{array}{l}80 \\
69\end{array}$ \\
\hline
\end{tabular}

from Calbiochem, Los Angeles, California, U.S.A.; [U-14 C]-L-aspartate, $\left[\mathrm{U}-{ }^{14} \mathrm{C}\right]-\mathrm{L}-\mathrm{valine}$, $\left[\mathrm{U}_{-14}{ }^{14} \mathrm{C}\right]-\mathrm{L}-$-isoleucine and $\left[\mathrm{U}-{ }^{14} \mathrm{C}\right]-\mathrm{L}-\mathrm{leucine}$ were obtained from the Radiochemical Centre, Amersham, Buckinghamshire.

\section{RESULTS}

Growth studies. Leucine, valine and isoleucine, singly or in combination, had no effect on the growth rate of Anabaena variabilis when they were included in the medium at concentrations between 0.5 and $6 \mathrm{~mm}$; they did, however, increase the lag phase of cultures by about one third. Other amino acids were likewise without effect on the growth rate of 


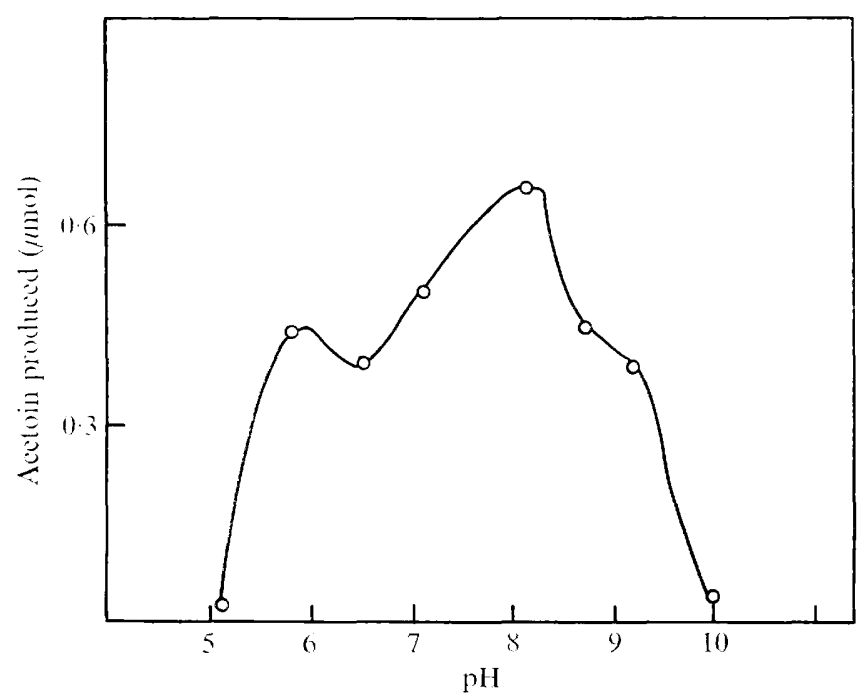

Fig. 2. Effect of $\mathrm{pH}$ on $\alpha$-acetohydroxyacid synthetase in extracts of Anabaena variabilis. The standard reaction mixture ( $5 \mathrm{mg}$ protein incubated for $2 \mathrm{~h}$ ) employed sodium acetate buffer, $\mathrm{pH} 5 \cdot \mathrm{I}$ and 5.8 ; potassium phosphate buffer, $\mathrm{pH} 6.5$ and $7 \cdot 0$; tris $\mathrm{HCl}, \mathrm{pH} 8 \cdot 0$ and $9 \cdot 0$; and glycine: $\mathrm{NaOH}, \mathrm{pH} 10^{\circ} 0$.

Table 2. Effect of branched-chain amino acids on the activity of $\alpha$-acetohydroxyacid synthetase from Anabaena variabilis and Ancystis nidulans

\begin{tabular}{|c|c|c|}
\hline \multirow{2}{*}{$\begin{array}{l}\text { Addition to the assay } \\
\text { reaction mixture }\end{array}$} & \multicolumn{2}{|c|}{ Rate $(\mathrm{nmol} / \mathrm{h} / \mathrm{mg})$} \\
\hline & A. variabilis & A. nidulans \\
\hline None & 27 & 42 \\
\hline L-Valine $(0.075 \mathrm{~mm})$ & I 8 & 23 \\
\hline L-Valine $(0.75 \mathrm{~mm})$ & I 7 & I 8 \\
\hline L-Leucine $(0.066 \mathrm{~mm})$ & 25 & 29 \\
\hline L-Leucine $(0.66 \mathrm{~mm})$ & 22 & 33 \\
\hline L-Isoleucine $(0.066 \mathrm{~mm})$ & 22 & 33 \\
\hline L-Isoleucine $(0.66 \mathrm{~mm})$ & $2 \mathrm{I}$ & 31 \\
\hline L-Valine $(0.75 \mathrm{~mm})$ & & \\
\hline $\left.\begin{array}{l}\text { L-Leucine }(0.66 \mathrm{~mm}) \\
\text { L-Isoleucine }(0.66 \mathrm{~mm})\end{array}\right\}$ & I5 & 19 \\
\hline
\end{tabular}

A. variabilis. However, slight stimulation $(20 \%)$ of the growth rate was observed when certain amino acids, including leucine, valine and isoleucine, were added at $2 \mathrm{~mm}$ concentration to cultures of Anacystis nidulans.

Although no stimulation of growth rate by exogenous amino acids was observed, $\mathrm{U}^{14} \mathrm{C}$ labelled valine, leucine and isoleucine were readily and linearly incorporated by growing cultures of Anabaena variabilis. Fractionation of the organisms indicated that the major part of the $\left[\mathrm{U}-{ }^{14} \mathrm{C}\right]$ valine incorporated was recovered in the protein fraction. When intact A. variabilis was hydrolysed and the constituent amino acids examined, only valine, and to a lesser extent leucine were radioactive.

Enzymes involved in branched-chain amino acid biosynthesis. No $\beta$-aspartokinase activity was detected in extracts of Anabaena variabilis, although the assay procedure employed was successful when applied to extracts of Escherichia coli. When $\left[\mathrm{U}-{ }^{14} \mathrm{C}\right]$ aspartate (Ioo $\mu \mathrm{Ci}$, 


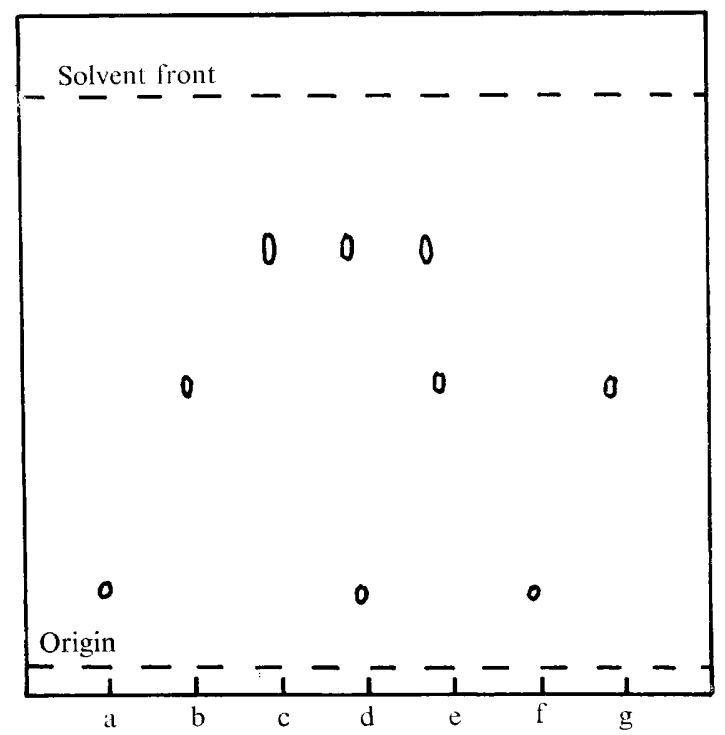

Fig. 3. Identification of the keto acid products of transaminase B in extracts of Anabaena variabilis. Descending paper chromatography in $n$-butanol:ethanol:water:ammonia (I40:20:40:I, by vol.). a, 2,4-Dinitrophenylhydrazone of authentic $\alpha$-oxoglutarate; b, 2,4-dinitrophenylhydrazone of authentic pyruvate; c, 2,4-dinitrophenylhydrazone of authentic $\alpha$-ketoisovalerate; $d, 2,4$-dinitrophenylhydrazones of assay mixure containing $\alpha$-ketoisovalerate and glutamate before extraction; e, 2,4-dinitrophenylhydrazones of assay mixture containing $\alpha$-ketoisovalerate and alanine before extraction; $\mathrm{f}$, as $\mathrm{d}$ except after extraction; $\mathrm{g}$, as e except after extraction.

Table 3. Variation in the components of the assay procedure for transaminase $B$ in extracts of Anabaena variabilis

$\begin{array}{lc}\text { Reaction mixture } & \begin{array}{c}\text { Rate } \\ \text { (nmol } / \mathbf{h} / \mathrm{mg})\end{array} \\ \text { Complete } & 85 \\ \text { - } \alpha \text {-Ketoisovalerate } & 0 \\ \text { - Pyridoxal phosphate } & 80 \\ \text { - Glutamate } & \text { I5 } \\ \text { - Glutamate } & \\ \text { + Alanine } & 50 \\ \text { - Glutamate } & \\ \text { + Aspartate } & 2 \mathrm{I}\end{array}$

$5 \mathrm{mM}$ ) was added to growth medium, it was readily incorporated, and subsequent hydrolysis and chromatography revealed radioactivity in both the aspartic family of amino acids (methionine, lysine, threonine and isoleucine) and those derived from glutamate (proline and arginine). Apparently, therefore, phosphorylation of aspartate, as the first stage in the biosynthesis of methionine, lysine, threonine and isoleucine, does occur and failure to demonstrate aspartokinase was artifactual. The presence of radioactivity in glutamate, arginine and proline suggests that some aspartate had been converted to oxaloacetate which could have given rise to $\alpha$-oxoglutarate and hence to glutamate, proline and arginine, The absence of a complete tricarboxylic acid cycle in A. variabilis (Pearce, Leach \& Carr, 1969) prevents complete randomization of the label from aspartate into other amino acids. Threonine deaminase was readily demonstrated in extracts of Anabaena variabilis. When 
this enzyme was assayed in the presence of low concentrations of isoleucine marked inhibition occurred (Fig. I $a$ ). Threonine deaminase activity was largely restored by increasing the substrate concentration, suggesting competitive inhibition of this enzyme by isoleucine; this inhibition was relieved by valine (Fig. I $b$ ). No repression of threonine deaminase was observed when $A$. variabilis was grown in the presence of isoleucine, or a combination of valine, leucine and isoleucine (Table I).

$\alpha$-Acetohydroxyacid synthetase was detected in extracts of Anabaena variabilis and Anacystis nidulans at low specific activities over a wide $\mathrm{pH}$ range with a minor peak of activity at $\mathrm{pH} 5.8$ and maximal activity at $\mathrm{pH} 8.0$ (Fig. 2 ). The inclusion in the assay mixture of branched-chain amino acids, either alone or in combination, was examined (Table 2). Valine was the most effective single inhibitor tested and a combination of valine, leucine and isoleucine gave a further slight increase in the inhibition of $\alpha$-acetohydroxyacid synthetase from $A$. variabilis. Valine was equally inhibitory to $\alpha$-acetohydroxyacid synthetase when tested at both peaks of activity, at $\mathrm{pH} 6 \cdot 0$ and $8 \cdot 0$.

Flavin adenine dinucleotide (I.6 mM) activated $\alpha$-acetohydroxyacid synthetase from Anabaena variabilis by nearly $100 \%$. In the presence of flavin adenine dinucleotide, valine $(0.5 \mathrm{~mm})$ still exerted its inhibitory effect on this enzyme. The addition of valine to the growth medium led to slightly lower activity of this enzyme in $A$. variabilis extracts, and inclusion of all three branched amino acids caused a $20 \%$ decrease in this organism and a $50 \%$ decrease in Anacystis nidulans (Table I). For comparison Escherichia coli was grown in the presence and absence of the branched-chain amino acids, which caused a reduction in $\alpha$-acetohydroxyacid synthetase of $75 \%$.

The procedure developed for the assay of transaminase B was based upon the different solubilities of the 2,4-dinitrophenylhydrazones of substrate keto acid ( $\alpha$-ketoisovalerate) and the product keto acid ( $\alpha$-oxoglutarate). Under the conditions employed, transaminase B activity was linear with protein concentration using extracts of both Escherichia coli and Anabaena variabilis. Both the keto acid and amino acid products of transaminase B activity in extracts of $A$. variabilis were identified chromotographically. The removal of the $2,4^{-}$ dinitrophenylhydrazine of the substrate keto acid ( $\alpha$-isoketovalerate) from that of the product keto acid ( $\alpha$-oxoglutarate or pyruvate) by the ethyl acetate and sodium carbonate extraction procedure is shown in Fig. 3. The formation of valine from $\alpha$-ketoisovalerate (and of leucine from $\alpha$-ketoisocaproate) was also demonstrated chromatographically (see Methods). Application of this assay procedure to the transamination of $\alpha$-ketoisocaproate to form leucine was limited by the non-quantitative extraction of the 2,4 -dinitrophenylhydrazone of $\alpha$-ketoisocaproate from ethyl acetate into sodium carbonate. Omission of $\alpha$-ketoisovalerate abolished activity, whilst less than $20 \%$ activity remained when the amino group donor, glutamate, was absent; alanine or aspartate were less effective as amino group donors (Table 3). Since the 2,4-dinitrophenylhydrazone derivatives of $\alpha$-oxaloacetate (from aspartate), $\alpha$-oxoglutarate (from glutamate), and pyruvate (from alanine) were extracted into sodium carbonate from ethyl acetate to the same extent the differences in enzyme activity shown in Table 3 were due to the specificity of the enzyme for the amino donor and not due to the differential solubility of the 2,4-dinitrophenylhydrazones of the product keto acids.

No repression of transaminase B was observed when Anabaena variabilis was grown in the presence of valine, leucine and isoleucine (Table I). However, measurement of the enzyme by the same procedure in Escherichia coli indicated that growth in the presence of the three branched-chain amino acids led to a reduction in specific activity from I I 40 to $390 \mathrm{nmol}$ oxoglutarate formed/h/mg. 
The conversion of valine,to leucine by Anabaena variabilis and the findings of Hoare, Hoare \& Moore (1967), who used isotopic techniques, that acetate can be converted to leucine in Anacystis nidulans, indicated that the enzyme $\alpha$-isopropylmalate synthetase was probably present in blue-green algae. Further evidence for this was obtained with extracts of $A$. variabilis in reaction mixtures containing all the components of the $\alpha$-isopropylmalate synthetase assay system were found to contain more free sulphydryl groups at the end of the incubation than controls lacking $\alpha$-ketoisovalerate. Although this was indicative of the presence of $\alpha$-isopropylmalate synthetase, the first of the three enzymes specific for leucine biosynthesis, the low levels of this enzyme and the inconsistent relationship between the enzymatic activity which could be measured and the protein concentration, made it unsuitable for studies of either end-product inhibition or repression.

\section{DISCUSSION}

The enzymes observed in extracts of the blue-green algae Anabaena variabilis indicate that pathways of biosynthesis of valine, isoleucine and leucine are similar to those described for bacteria (Meister, I957) and therefore $\alpha$-acetohydroxyacid synthetase and transaminase $\mathrm{B}$ are necessary for biosynthesis of all three amino acids. The incorporation of $\left[{ }^{14} \mathrm{C}\right]-$ leucine, valine and isoleucine by Anabaena variabilis indicated that the observed absence of significant repression of the branched-chain amino acid biosynthetic enzymes in this organism was not due to the impermeability of the micro-organism to these compounds. The slightly reduced level of $\alpha$-acetohydroxyacid synthetase in $A$. variabilis after growth in the presence of the three branched-chain amino acids may present partial repression of the enzyme, but more probably this was due to an inhibitive effect of the exogenous amino acids. A greater reduction of the enzyme level is seen in Escherichia coli grown under the same conditions. The level of $\alpha$-acetohydroxyacid synthetase in valine-grown $A$. variabilis was certainly no lower than in minimally grown organisms and this contrasts with those bacteria where valine represses this enzyme (Halpern \& Umbarger, I959; Radhakrishnan $\&$ Snell, 1960). Neither threonine deaminase nor transaminase B were repressed when the three branched-chain amino acids were included in the growth medium of A. variabilis, again contrasting with other micro-organisms examined (Freundlich, Burns \& Umbarger, 1 962; Dwyer \& Umbarger, I 968; Bussey \& Umbarger, I969; Magee \& Hereford 1969). However Barritt (197I) did not observe any repression or derepression of threonine deaminase in wild-type or in an isoleucine-valine auxotrophic Rhodopseudomonas spheroides, although the activity of this enzyme was inhibited by isoleucine, and valine reversed this inhibition. The extent to which feedback inhibition, in the absence of transcriptional control, permits an organism to adjust its biosynthetic activities is not known, although it may be relevant to note that mutant strains of Salmonella typhimurium excrete leucine into the medium when either type of control has been lost (Calvo \& Calvo, 1967). It appears that repression of enzymes involved in amino acid biosynthesis does not occur in the blue-green algae examined, at least in respect of the synthesis of branched-chain amino acids, arginine (Hood, Leaver \& Carr, I969; Hood \& Carr, I97I) and aromatic amino acids (Weber \& Böck, I968).

The work was supported in part by the Science Research Council; W. H. acknowledges receipt of a Medical Research Council postgraduate studentship. 


\section{REFERENCES}

BARRITT, G. J. (1971). Biosynthesis of isoleucine and valine in Rhodopseudomonas spheroides. Regulation of threonine deaminase activity. Journal of Bacteriology 105, 71 8-721.

BLACK, S. \& Wright, N. G. (1955). $\beta$-Aspartokinase and $\beta$-aspartyl phosphate. Journal of Biological Chemistry 213, 27-38.

Burns, R. O., Calvo, J., Margolin P. \& Umbarger, H. E. (I966). Expression of the leucine operon. Journal of Bacteriology 91, I570-1576.

Bussey, H. \& UMBARGER, H. E. (1969). Biosynthesis of branched-chain amino acids in yeast: Regulation of synthesis of the enzymes of isoleucine and valine biosynthesis. Journal of Bacteriology 98, 623628.

Calvo, R. \& Calvo, J. M. (1967). Lack of end-product inhibition and repression of leucine synthesis in a strain of Salmonella typhimurium. Science, New York 156, I $107-\mathrm{I} 109$.

Davis, B. D. \& Mingiol, E. S. (1950). Mutants of Escherichia coli requiring methionine or vitamin $\mathrm{B}_{12}$. Journal of Bacteriology 6o, 17-28.

DWYer, S. B. \& UMBarger, H. E. (I968). Isoleucine and valine metabolism in Escherichia coli XVI. Pattern of multivalent repression in strain K-12. Journal of Bacteriology 95, $1680-1684$.

Freundlich, M., Burns, O. R. \& Umbarger, H. E. (1962). Control of isoleucine, valine and leucine biosynthesis. I. Multivalent repression. Proccedings of the National Academy of Sciences of the United States of America 48, I804-1808.

Frifdemann, T. E. \& Haugen, G. E. (I943). Pyruvic acid. II. The determination of keto acids in blood and urine. Journal of Biological Chemistry 147, 415-442.

Grunert, R. R. \& Phillips, P. H. (I95I). A modification of the nitroprusside method of analysis for glutathione. Archives of Biochemistry 30, 21 7-225.

HALPERN, Y.S. \& UMBARGER, H. E. (1959). Evidence for two distinct enzyme systems forming acetolactate in Aerobacter aerogenes. Journal of Biological Chemistry 234, 3067-307I.

Hoare, D. S., HoAre, S. L. \& MoOre, R. B. ( 1967$)$. The photo-assimilation of organic compounds by autotrophic blue-green algae. Journal of General Microbiology 49, 35I-370.

Hoon, W. \& CARR, N. G. (1968). Threonine deaminase and acetolactate synthetase in Anabaena variabilis. Biochemical Journal I09, $4 \mathrm{P}$.

HooD, W. \& CARR, N. G. (I971). Apparent lack of control by repression of arginine metabolism in bluegreen algae. Journal of Bacteriology 107, 365-367.

Hood, W., Leaver, A. G. \& CARR, N. G. (1969). Extracellular nitrogen and the control of arginine biosynthesis in Anabaena variabilis. Biochemical Journal I14, I2-13P.

Kratz, W. A. \& MYers, J. (I955). Nutrition and growth of several blue-green algae. American Journal of Botany 42, 282-287.

LEAvitT, R. I. \& UMBARGER, H. E. (1962). Isoleucine and valine metabolism in Escherichia coli. XI. Valine inhibition of the growth of Escherichia coli strain K-I2. Journal of Bacteriology 83, 624-630.

LipmanN, F. \& TuttLe, C. L. (1945). A specific micromethod for the determination of acyl phosphates. Journal of Biological Chemistry 159, $2 \mathrm{I}-28$.

Magee, P. T. \& Hereford, L. M. (1969). Multivalent repression of isoleucine-valine biosynthesis in Saccharomyces cerevisiae. Journal of Bacteriology 98, 857-862.

MeISTER, A. (1957). Biochemistry of Amino Acids, p. 485. New York: Academic Press.

PeARCE, J. \& CARR, N. G. (1967). The metabolism of acetate by the blue-green algae, Anabaena variabilis and Anacystis nidulans. Journal of General Microbiology 49, 30I-3 I 3 .

Pearce, J. \& Carr, N. G. (I969). The incorporation and metabolism of glucose by Anabaena variabilis. Journal of General Microbiology 54, 451-462.

Pearce, J., Leach, C. K. \& Carr, N. G. (1969). The incomplete tricarboxylic acid cycle in the blue-green alga, Anabaena variabilis. Journal of General Microbiology 55, 37I-378.

Radhakrishnan, A. N. \& SNell, E. E. (1960). Biosynthesis of valine and isoleucine. II. Formation of $\alpha$-acetolactate and $\alpha$-aceto-2-hydroxglutyrate in Neurospora crassa and Escherichia coli. Journal of Biological Chemistry 235, 2316-232 I.

Roberts, R. B., Cowie, D. B., Abelson, P. H., Bolton, E. T. \& Britten, R. J. (1955). Studies of Biosynthesis in Escherichia coli, p. 521. Carnegie Institute of Washington Publication 607. Washington: Carnegie Institute.

Umbarger, H. E. (1969). Regulation of amino acid metabolism. Annual Review of Biochemistry 38, 323-370. 
WEBER, H. L. \& BöCK, A. (I968). Comparative studies on the regulation of DAHP synthetase activity in blue-green and green algae. Archiv für Mikrobiologie 61, 159-168.

Westerfeld, W. W. (1945). A colorimetric determination of blood acetoin. Journal of Biological Chemistry I6r, 495-502.

YANOFSKY, C. \& REISSIG, J. L. ( I 953). L-Serine dehydrase of Neurospora. Journal of Biological Chemistry 202, $567-577$. 